\title{
The Influence of the Avaivartikacakra Mahãyāna Sūtra in Indian Buddhism Based on Its Citation in Indian Buddhist Commentaries
}

\author{
James B. ApPLE
}

\section{Introduction}

A significant, yet previously unstudied, self-proclaimed Mahāyāna scripture, is the Avaivartikacakrasūtra ('The Discourse on Irreversibility'). 1) The Avaivartikacakrasūtra is an early Mahāyāna scripture that focuses on the concept of the irreversibility (avaivartika) of bodhisattvas ("Buddhas-in-training") from the attainment of full Buddhahood. The concept of the irreversible (avaivartika) bodhisattva is considered to be one of the most vital subjects in the historical development of Mahāyāna Buddhism due to the concept's prevalence, as well as its transvaluing meaning, in early (pre-3rd century) Mahāyāna literature. ${ }^{2)}$ The Avaivartikacakrasütra provides the earliest and most comprehensive discussion of this concept among Mahāyāna scriptures other than the Prajñāpāramitā literature. The sūtra is also notable for its advocation of ekayāna, its usage of narrative displacement, and its rhetoric of 'word-play' through semantic elucidation or nirukti. ${ }^{3)}$ One may infer that this text was an influential Mahāyāna sūtra in Buddhist culture as indicated by its preservation and transmission in South, Central, and East Asia over many centuries. ${ }^{4)}$

\section{Citations in Indian Buddhist Commentaries}

The importance of the Avaivartikacakrasūtra is also demonstrated through its active citation in indigenous commentaries on the bodhisattva path by prominent Indian Mahāyāna Buddhist scholars from the second to twelfth centuries. Previous studies have discussed how Indian masters' citations of a sūtra demonstrate the importance of a particular sütra within the historical context of Indian Buddhism. ${ }^{5)}$ As we will see, the Avaivartikacakrasütra was an important text to support the views of a number of Indian Buddhist scholars.

\subsection{Sūtrasamuccaya}

The Sütrasamuccaya is an anthology of sūtra citations traditionally attributed to Nāgār- 
juna, although recent discussion in modern scholarship has indicated that the author may be different from the Nāgārjuna who composed the Madhyamakakārikā. Nevertheless, the anthology had great influence on later Indian Buddhist scholarship. The author of the Sütrasamuccaya cites the following portion from Avaivartikacakrasūtra to substantiate his view on ekayāna:

Mañjuśrī asked, "To what extent is this compatible with the dharma teachings of the Buddhas, the Blessed Ones?" [The Bhagavan [" Ābhāvṛtapadmaphullitagātra] replied], "The dharma teaching of the Buddhas, the Blessed Ones, is compatible with the discourse on irreversible dharma (avaivartikadharmacakra)." [The bodhisattva] asked, "Bhagavan, How is it that a Bhagavan sets forth the three vehicles and presently teaches dharma? [The Bhagavan [* Ābhāvṛtapadmaphullitagātra] replied] "Son of Good Family, sentient beings aspire for the inferior and when they do not enter the single vehicle, [the Buddhas] guide them with skill in means. Son of Good Family, the Buddhas, the Blessed Ones, have great skill in means. The Blessed One appears to those [sentient beings] at the time of the five degenerations and uses skill in means for those who do not aspire for the single vehicle. ${ }^{6)}$

The citation is from the first chapter of the Avaivartikacakrasütra although, in this section of the sūtra itself, the discussion does not involve Mañjuśri but rather the bodhisattva Pleasant Sound ( ${ }^{*} \bar{A}$ nandokti, Tib. sgra snyan).

\section{2. Ārya Vimuktisena (6th century) and Haribhadra (8th century)}

The Avaivartikacakrasūtra was popular among commentators of the Abhisamayālamkāra as a number of commentators to this śästra make reference to the sütra. We know the Sanskrit title of the text as Avaivartikacakrasütra since the title of the sütra is preserved in the Abhisamayālamkāra commentaries of both Ārya-Vimuktisena and Haribhadra, ${ }^{7)}$ despite notable discrepancies among reconstructed titles preserved in the various editions of the Tibetan Kanjur. ${ }^{8)}$ Ārya-Vimuktisena and Haribhadra reference the Avaivartikacakrasūtra in order to illustrate how the twenty types of samgha mentioned in verses 1.23-24 of the Abhisamayālamkāara are bodhisattvas. ${ }^{9)}$ Other Indian Abhisamayālamkāra commentators will reference the Avaivartikacakrasūtra as well, with Dharmamitra in his Prasphuțapada (D 3796) providing several citations from the sütra itself:

Here, the teaching refers to the bodhisattva as a Stream-enterer and so forth since both the basis of a term and the emanator are emanantions and, since sentient beings are known to be afraid of the great waves of the sublime vehicle and aspire for the inferior, bodhisattvas become śāvakas and are indicated to achieve pratyekabuddha awakening. It is construed through the basis of a term [, the 
Avaivartikacakrasūtra states]:

"The unfabricated, unstained, passionless realm is indicated, it is indicated having perceived all the buddha-qualities.

That which the Buddhas teach does not conceptualize things afar nor conceptualize things near, therefore, their teachings are uncontaminated.

Proclaiming the contaminated to not exist, elucidated to immeasurable sentient beings, Those sentient beings do not see. In this way, a bodhisattva is called a śrāvaka.

Ānanda, with this intention, I have thoroughly taught [the meaning of] śrāvaka. Unrestricted is a bodhisattva, and therefore [a bodhisattva] should be known as a śrāvaka.'

Likewise: 'Having understood these conditions, a bodhisattva is unrestricted and I have indicated a bodhisattva with the term "pratyekabuddha."'

Further, these bodhisattvas are taught with the basis of the word having three distinctions for the Stream-enterer and so forth. This is cited from the Arya-avaivartikacakrasütra. ${ }^{10)}$

\subsection{Bhāviveka (6th century) and Candrakīrti (7th century)}

An unacknowledged Sanskrit verse from the Avaivartikacakrasūtra is preserved in Candrakirti's Prasannapadā, and the verse is unattributed in the Tibetan translations of Bhāviveka's Prajñāpradīpa and Avalokitavrata's Prajñāpradīpațīkā. The Sanskrit as preserved in Poussin's edition of the Prasannapadă, which is based on 18th century manuscripts from Nepal, is as follows:

anirvānam hi nirvānam lokanāthena deśitam /

ākāśena krto granthir ākāśenaiva mocitah // ${ }^{11)}$

"The leader of the world has taught that there is no nirvāna in nirvāna.

A knot tied in space is released through space itself."

The verse is cited in the commentaries in the context of the twenty-fifth chapter of Nāgārjuna's Madhyamakaśāstra that analyzes nirvāna. The earliest commentary to cite the verse is Bhāviveka in his Prajñāpradipa. ${ }^{12)}$ Bhāviveka does not state the textual source for the verse whereas the $t \bar{l} k \bar{a}$ subcommentary to Bhāviveka by Avalokitavrata notes the source of the verse as "the extensive Mahāyāna sūtras." "13) Likewise, Candrakīrti cites the verse as spoken by the Bhagavan (Poussin 1970: 540: uktam ca bhagavatā), but in the context of the Avaivartikacakrasütra the verse is spoken by Ānanda at the beginning of the eleventh chapter. ${ }^{14)}$ The version of the verse as it occurs in the 12th century the Tibetan Prasannapada translation of Kanakavarma and Pa-tshab nyi-ma grags is the version most cited in Tibetan commentaries. Just as the Tibetan commentaries do not recognize the source of the verse, I have located at least five Euro-American articles and books that do not source this 
verse either, even as the verse is a favorite among those who study Buddhist philosophy. ${ }^{15)}$

\subsection{Avalokitavrata (late 7 th century)}

I have argued in recent publications that the Avaivartikacakrasütra is one among several early Mahāyāna sūtras that utilize nirukti, or semantic elucidation, as a form of rhetoric to transvalue mainstream Buddhist categories into bodhisattva embodied values. ${ }^{16)}$ The claim that such Mahāyāna sūtras like the Avaivartikacakrasūtra are employing nirukti is also found among traditional commentators, although the underlying purport for traditional authors may be different from my modern critical standpoint. Avalokitavrata (late 7th century?) cites the Avaivartikacakrasūtra three times in his Prajñāpradipațika (D 3859) to provide nirukti for the terms bhagavan, tathägata, and buddha. Avalokitavrata's citation for tathägata is as follows:

Or in another way, the Blessed One has stated a semantic elucidation from the Arya-avaivartikacakrasūtra: "In the way that childish beings have imputed, in that way awakening is not found, since all things cannot be found, therefore, he is called Tathāgata." 17)

Avalokitavrata is not the only traditional commentator to cite the Avaivartikacakrasūtra for the Buddha's use of semantic elucidation.

\subsection{Kamalasīla (740-795 CE)}

Kamalaśilla also cites from the Avaivartikacakrasütra to illustrate semantic elucidation in the comments within his Arya-Avikalpapraveśadhäraṇițikā (D 4000):

Or in another way, he is completely free from fear since he has attained the four fearlessnesses, by means of semantic elucidation one calls a 'bhagavan' as such as stated from the Arya-avaivartikacakrasūtra: "He thorougly indicates (pradarsitah) to living beings (dehinām) that things are similar to space. He is fearless (nirbhayatā) with respect to that. Therefore, he is called 'Bhagavan."'18)

In addition to semantic elucidation, Kamalasilla quotes the Avaivartikacakrasūtra in his Madhyamakāloka (D 3887) to support his view of ekayāna:

... one should understand that teaching the three vehicles is a teaching that is itself skill-in-means. If it is not like this, there will be only contradiction with all that was formerly explained. The Avaivartikacakrasütra states that "the teaching of dharma by all the Buddhas in every world-realm is similar to the irreversible wheel (avaivartikacakra). In this regard, the sentient beings of the Sahā world-realm who appear at the time of the five corruptions aspire to the inferior and, since [they initially] do not enter into the teaching of the single vehicle (ekayāna), sentient beings are directed to Buddhahood through this method [of skill-in-means]."19) 


\subsection{Other References to Avaivartikacakrasūtra}

Several scholars make reference to an "avaivartikacakrasūtra" ('phags pa phyir mi ldog pa' $i$ 'khor lo' $i$ mdo), although they are not actually citing the Avaivartikacakrasūtra Mahāyāna scripture, but rather, are referencing either a section of the Prajñāpāramitā or the Dhāraṇiśvararājaparivarta. In the Samskṛtāsamskṛtaviniścaya ${ }^{20)}$ of Daśabalaśrīmitra reference is made to an avaivartikacakrasūtra ('phags pa phyir mi ldog pa'i 'khor lo'i mdo) when discussing the realization of the bodily witness $(k \bar{a} y a s a \bar{a} k s i ̄ n) .{ }^{21)}$ However, Daśabalaśrīmitra is referencing a section of the Pañcavimśatiprajñāpāramitāa. Likewise, Abhayākaragupta in his Munimatālamkāra ${ }^{22)}$ claims that Candrakirti, in the last chapter of the Madhyamakāvatāra (verses 12.8-9), is a follower of the "avaivartikacakrasūtra" since Candrakirti explains that the unproduced dharma-body is realized by the sambhoga$k \bar{a} y a$. However, this reference to the "avaivartikacakrasūtra" is indicating the Dhāraṇiśvararājaparivarta, not the Avaivartikacakrasūtra Mahāyāna sūtra. The Dhāraṇiśvararājaparivarta teaches three wheels of dharma, the third of which is known as the "irreversible wheel of dharma" (avaivartikacakra) ${ }^{23)}$ Candrakirti cites this sütra extensively in the later portion of his Madhyamakāvatārabhāsya.

\section{Conclusion}

I have briefly demonstrated the influence of the Avaivartikacakrasütra in Indian Buddhism through citations of the sūtra in Indian Buddhist śāstras. The authors of such technical digests generally cite the Avaivartikacakrasūtra Mahāyāna scripture as a scriptural authority (āgama) for one of four purposes: to support the claims of one universal vehicle (ekayāna), to demonstrate the Buddha's use of semantic elucidations (nirukti), to illustrate that Stream-enterers, Once-returners, Non-returners, and so forth are actually bodhisattvas, and to illustrate the non-conceptuality of nirvāṇa.

1) James B. Apple, Stairway to Nirvāna: A Study of the Twenty Samghas Based on the Works of Tsong Kha Pa (Albany: State University of New York Press, 2008). Ratna Handurukande, "Avaivartacakra-Nāma-Mahāyāna-Sūtra," Encyclopaedia of Buddhism 2.3 (1973) , 400-402.

2 ) James Apple, "An Assembly of Irreversible Bodhisattvas. Twenty Varieties of the Samgha: A Typology of Noble Beings (Ārya) in Indo-Tibetan Scholasticism (Part 2)," Journal of Indian Philosophy 32 (2004): 211-279. James B. Apple, "On Avaivartika and Avaivartikacakra in Mahāyāna Buddhist Literature with Special Reference to the Lotus Sūtra," Bulletin of the Institute of Oriental Philosophy, 
no. 27 (2011): 119-147.

3) James B. Apple, “'Wordplay': Emergent Ideology through Semantic Elucidation. A Rhetorical Technique in Mahāyāna Buddhist Formations," Bulletin for the Institute of Oriental Philosophy 25 (2009): 161-173.

4) The Avaivartikacakra Mahāyāna sūtra is no longer extant in any Indic language but is preserved in Chinese, Tibetan, Manchu, and Mongolian translations. Three translations of this sütra are preserved in Chinese translation. The first is the Aweiyuezhizhe jing 阿維越致遮經 (T. 266) translated by Dharmarakșa in four juan on the 14th day, 10th month, 5th year of Taikang 泰康, Western Jin (西 晉) dynasty (November 8th, AD 284) in Dunhuang 敦煌. The second translation is the Butuizhuanfalun jing 不退轉法輪經 (T. 267) translated during the Northern Liang (北涼) dynasty (AD 412-439). The third translation is the Guangboyanjing butuizhuanlun jing 廣博樷淨不退轉輪經 (T.268) translated by Zhiyan 智厳 during the 4th year of Yuanjia 元嘉, Liusong 劉宋 dynasty (AD 427) in Zhiyuan Monastery (枳園寺) in Yangdu 楊都. The 9th century Tibetan translation is preserved in all Tibetan Kanjurs including Derge (no. 240) and Peking (no. 906).

5 ) Jens Braarvig, Akșayamatinirdeśasūtra, two Volumes (Oslo: Solum, 1993). Kaie Mochizuki, "How Did the Indian Masters Read the Lotus Sūtra?" Journal of Indian and Buddhist Studies, vol. 59, no. 3 (2011): (95-103) 1169-1177.

6 ) Avaivartikacakrasūtra, Derge, D, mdo sde zha 243a3-6. See Pāsādika, ed., Nāgārjuna's Sūtrasamuccaya: A Critical Edition of the mDo kun las btus pa (Copenhagen: Akademisk Forlag I Kommission, 1989) on the tenth theme (j) theg pa gcig la mos pa'i sems can de dag ni shin tu rnyed par dka'stel, 130.15-131.5.

7 ) See Corrado Pensa, ed., L'Abhisamayālaṃkāravrtti di Ārya-Vimuktisena: Primo Abhisamaya; Testo e note crit (Roma: Is.M.E.O., 1967), 46: "Avaivartikacakra sūtre," and Unrai Wogihara, ed., Abhisamayālamkār'ālokā prajñāpāramitāvyākhyā (Commentary on Aștasāhasrikā-prajñāpāramitā) (Tokyo: Toyo Bunko, 1932), 36.8: "avaivartikacakra sūtra."

8 ) For example, the Berlin manuscript (B) provides the title āryāvivartacakra-nāma-mahāyānasūtra and āryāvevartacakra-nāma-mahāyāana-sūtra. Stogs palace (S) gives the title as ārya-avaivartikacakra-nāma-mahāyāna-sūtra. The Bathang Newark manuscript $(\mathrm{Ne})$ gives aryavevartyacakranāma-mahāyānasūtra. Tabo fragment (Rn027) gives the title as aryavenivartyacakra-nama-mahayānasutra.

9 ) See Apple 2004, 2008.

10) Dharmamitra discusses this at D. No. 3796, 45b1-6. The Prasphuțapadā is a tịkā commentary on Haribhadra's Abhisamayālaṃkāraśāstravivṛti.

11) Louis de La Vallée Poussin, ed., [Madhyamakavrttih] : Mūlamadhyamakārikās (Mādhyamikasūtras) de Nāgārjuna avec la Prasannapadā commentaire de Candrakìrti (Osnabrück: Biblio Verlag, 1970), 540.

12) Prajñāpradipamūlamadhyamakavrtti, D. No. 3853, 248 b.

13) Prajñāpradipațikā, D. No. 3859: 304a.

14) James B. Apple, The Avaivartikacakrasütra: A Critical Edition of the Tibetan Text based on Eigh- 
teen Editions of the Kanjur (forthcoming).

15) See C. W. Huntington, The Emptiness of Emptiness an Introduction to Early Indian Madhyamika (Honolulu: University of Hawaii Press, 1989), 201n28; Th. Stcherbatsky, The Conception of Buddhist Nirvana [with Sanskrit Text of Madhyamaka-Kārikā], reprint of Second Revised and Enlarged Edition (New Delhi [u.a.]: Motilal Banarsidass, 1978), 221; Christian Lindtner, Miscellanea buddhica (Kobenhavn: Akademisk Forlag, 1985); Guy Bugault, Stances du milieu par excellence de Nāgārjuna= Madhyamaka-kārikās (Paris: Gallimard, 2002), 335.

16) See Apple 2009.

17) Prajñāpradīpatịka, D. No. 3859: 21a6-7, 10a5, 44b7-45a1.

18) Árya-Avikalpapraveśadhāranițîkā, D. No. 4000: 126a-b.

19) Madhyamakāloka-nāma, D. No. 3887: 241 a4-7.

20) On this text see the work of Peter Skilling: "The Samskṛtāsamskṛta-viniścaya of Daśabalaśrimitra," Buddhist Studies Review, vol. 4, no. 1 (1987): 3-23; "The Sixty-Four Destructions according to the Saṃskṛtāsamskṛtaviniścaya," Journal of the Pali Text Society, vol. 25 (1999) : 113-120; "Vimuttimagga and Abhayagiri: The Form-Aggregate according to the Samskṛtāsamskṛtaviniścaya," Journal of the Pali Text Society, vol. 20 (1994): 171-210.

21) Samskrtāsamskrtaviniścaya, D. No. 3897, 285b6-7.

22) Munimatālamkāra, D. No. 3903, 208a-b.

23) The Dhäraniśsvararājaparivarta has two versions extant in Chinese, Tuoluonizizaiwangpusapin 陀羅尼自在王菩薩品 (T. 397, juan 1-4) and the Mahākarunāsūtra, Daaijing 大哀經 (T. 398). The Tibetan version of the sūtra is preserved in chapter 1 and 2 of the Tathāgatamahākarunanirdeśa (D mdo sde Pa 142a-242b). Tibetan commentators discuss this sütra's teaching of three wheels in connection with the Ratnagotravibhāgavyākhyā. See Klaus-Dieter Mathes, A Direct Path to the Buddha Within: Gö Lotsawa's Mahāmudrā Interpretation of the Ratnagotravibhāga (Boston: Wisdom Publications, 2008).

(This work was supported by a Grant-in-Aid of Social Sciences and Humanities Research Council in Canada)

〈Key words〉 Avaivartikacakrasūtra, nirukti, ekayāna, Candrakīrti, Kamalaśīla

(Associate Professor, University of Calgary) 